\author{
ANNA MAJEWSKA \\ Uniwersytet Łódzki \\ ORCID: 0000-0003-0589-6400 \\ anna.majewska@op.pl
}

\title{
PRZEKSZTALCENIA KRAJOBRAZU W MIEJSCOWOŚCIACH DAWNYCH PRUS WSCHODNICH PO DELIMITACJI GRANICY POLSKO-ROSYJSKIEJ
}

\section{Transformation of Urban Landscape in the Former East Prussia after the Delimitation of the Polish-Russian Border}

The article deals with the transformation of landscape following the delimitation of a state border using the example of the contemporary Polish-Russian borderland. Changes in the material structures of the settlement network and depopulation concern, in particular, localities whose areas have been divided by the border line and those located in the immediate vicinity (within $5 \mathrm{~km}$ ). Numerous relics of completely depopulated settlement units identified in this space are objects that stand out in the borderland landscape. Thus, they co-create the contemporary landscape identity. The article presents the results of a historical and geographical analysis, showing the distribution of rural settlement units that were liquidated or abandoned as a result of geopolitical changes related to the end of World War II. Moreover, landscape relics of depopulated localities have been identified using measurement data from airborne laser scanning. The destructed objects identified in the historical settlement are among the components of the material memory of the local landscape. They are evidence of the events and socio-political processes that took place over the last few decades in the lands of former East Prussia incorporated into Poland, in particular during the time associated with the delimitation of the current state border.

Keywords: landscape studies, borderland, political geography, historical geography, contemporary archaeology, abandoned villages, LiDAR, relics of settlement. 


\section{WPROWADZENIE}

Przestrzeń każdego pogranicza jest nie tylko nośnikiem pamięci o wydarzeniach i procesach, ale także posiada własna materialna pamięć. Na północno-wschodnim pograniczu współczesnej Polski miejscami jej koncentracji są w szczególności jednostki osadnicze stanowiące węzłowe punkty lokalnego krajobrazu kulturowego. Jako złożone struktury krajobrazowe współkształtowane przez kulturę i naturę, czynniki wewnętrzne i zewnętrzne, odzwierciedlaja charakter i przebieg procesów historycznych, w wymiarach: politycznym, społecznym i gospodarczym. Ich obecne obszary to reprezentacje fizycznych przekształceń, jakie zaszły w krajobrazie dawnej wschodniopruskiej prowincji, po podzieleniu jej granica polsko-rosyjska. Przede wszystkim dotyczy to tych $z$ miejscowości, które w wyniku decyzji politycznych znalazły się na linii przebiegu granicy lub w jej pobliżu. Ich krajobrazy „opowiadaja” o wydarzeniach zwłaszcza końca drugiej wojny światowej i kilku powojennych dekad, które w największym stopniu nakreśliły ich dalsze funkcjonowanie, w tym kres ich dalszego trwania jako zamieszkanych jednostek osadniczych.

Przedmiotem opracowania sa przemiany krajobrazu fizycznego miejscowości, stanowiące następstwa delimitacji granicy polsko-radzieckiej, przeprowadzonej po zakończeniu drugiej wojny światowej ${ }^{1}$. Zasadniczym celem podjętych badań była identyfikacja miejscowości, których przestrzenie zostały podzielone granica państwowa, a następnie określenie stopnia koncentracji wyludnionych miejscowości na terenach przygranicznych oraz rodzajów i kierunków przemian zachodzacych w wybranych opuszczonych jednostkach osadniczych.

Do podzielonych jednostek osadniczych należa przede wszystkim całkowicie wyludnione miejscowości. Ich przestrzenie przeanalizowane w ujęciu horyzontalnym zostały sprowadzone do postaci kartograficznej interpretacji ich struktur materialnych. Analizie poddano ich wybrane składowe oraz najbliższe otoczenie (np. określono rodzaje i zmiany pokrycia terenu w okręgach o promieniu $1 \mathrm{~km}$ od centroidów siedlisk miejscowości).

Istotne ogniwo, majacego tu zastosowanie tła teoretycznego, stanowi koncepcja materialnej pamięci krajobrazu zaproponowana przez

\footnotetext{
Opracowanie zawiera wyniki badań, zrealizowanych w ramach projektu badawczego nt. Pamięć krajobrazu zanikajacych miejscowości z terenu dawnych Prus Wschodnich - materialny wymiar przerwania ciagłości osadnictwa, sfinansowanego w ramach programu grantowego Preludium 15 Narodowego Centrum Nauki (nr rej. projektu: 2018/29/N/ HS3/01001) - stanowiących część realizowanej rozprawy doktorskiej.
} 
Urszulę Mygę-Piątek² ${ }^{2}$ Została zaadaptowana jako swego rodzaju oś prowadzenia wywodu, ponieważ koresponduje $z$ charakterem przekształceń zachodzących w krajobrazie kulturowym dawnego - historycznego i obecnego - reliktowego pogranicza. W pracy przyjęto koncepcje pamięci krajobrazu w perspektywie materialnej, według której wydarzenia historyczne odczytuje się za pośrednictwem obiektów i struktur, które na skutek różnych procesów zostały zapisane i utrwalone w krajobrazie, współtworząc jego współczesną strukturę ${ }^{3}$. Składniki krajobrazu fizycznego, w ramach tej materialnej perspektywy prowadzenia analizy, stanowia „materialna pamięć, „nośniki pamięci”, sa „nie ludzkimi świadkami” wydarzeń oraz „nie ludzkimi ocalałymi”, bądź w zależności od kontekstu „nie ludzkimi ocalonymi”.

Przedstawione analizy stanowią część badań dotyczących materialnego wymiaru przerwania ciagłości osadnictwa w miejscowościach znajdujących się we włączonej do Polski części dawnych Prus Wschodnich. W szerszym ujęciu zagadnienia przedstawione $\mathrm{w}$ opracowaniu sa zatem składowymi odpowiedzi na pytania o to:

- Jaki jest materialny wymiar przerwania ciagłości osadnictwa w polskiej części dawnych Prus Wschodnich?

- Co dzieje się obecnie $z$ niezamieszkanymi miejscowościami?

- Jakie informacje przechowuja relikty ich struktur materialnych, czyli co można odczytać z tzw. pamięci krajobrazu wyludnionych miejscowości?

\section{DELIMITACJA GRANICY I POWOJENNA SYTUACJA SPOŁECZNO-POLITYCZNA NA OBSZARZE POGRANICZA}

Michał Sobala ${ }^{4}$ zakłada, że „wszelkie przejawy działalności człowieka, a co za tym idzie związane $z$ nimi elementy krajobrazu, nawiazują do wyznaczonych przez niego granic" i dalej, że:

[...] efektem rozdzielenia obszarów umownymi granicami może być ich wtórne zróżnicowanie, spowodowane odmiennym sposobem traktowania przez człowieka obszarów po obu stronach linii granicznej.

Istotnie, decyzja o wytyczeniu granicy polsko-rosyjskiej zapoczątkowała kształtowanie krajobrazu kulturowego nowego pogranicza.

\footnotetext{
2 U. Myga-Piątek, Pamięć krajobrazu - zapis dziejów w przestrzeni, „Studia Geohistorica" 2015, t. 3, s. 35.

3 Por. ibidem.

4 M. Sobala, Rola materiałów kartograficznych $w$ wyznaczaniu granic obszaru badań zmian krajobrazu kulturowego, „Prace Komisji Krajobrazu Kulturowego. Żródła kartograficzne w badaniach krajobrazu kulturowego" 2012, nr 16, s. 105-115.
} 
Prusy Wschodnie postanowieniem konferencji poczdamskiej po drugiej wojnie światowej podzielone zostały między Polskę i Związek Radziecki. Rozdzielenie stanowiących dotychczas jedność ziem byłej już niemieckiej prowincji stanowiło jednak proces, który odbywał się stopniowo, współokreślając zmiany tamtejszego krajobrazu kulturowego. Przebieg granicy polsko-radzieckiej zatwierdziła umowa zawarta w Moskwie 16 sierpnia 1945 roku. Krajobrazowe konsekwencje decyzji o ustaleniu granicy nie były widoczne od razu po podpisaniu umowy, ponieważ przebieg granicy w terenie wytyczany był kolejne dwa lata przez powołana $\mathrm{w}$ tym celu polsko-radziecka komisję delimitacyjna 5 . Radzieckie wojska pogranicza, jak podaje Andrzej Wakar $^{6}$, w ciagu 1945 roku i jeszcze na początku 1946 roku wielokrotnie przesuwały usytuowanie swoich posterunków, dokonujac tym samym niewielkich, lokalnych zmian przebiegu granicy państwowej.

Stanowiło to m.in. konsekwencje tego, że polsko-radziecki układ graniczny z sierpnia 1945 roku został ogłoszony w polskim Dzienniku Ustaw dopiero w kwietniu $1947 \mathrm{roku}^{7}$. Między innymi w listopadzie 1945 roku władze radzieckie wydały staroście powiatu gierdawskiego - którego ostatecznie ok. jednej czwartej powierzchni przyznano Polsce - nakaz opuszczenia powiatu i to zarówno urzędów, jak i całej ludności polskiej. Wówczas granica została przesunięta $12-14 \mathrm{~km}$ na południe, a osiedlanie się ludności polskiej zostało wzbronione ${ }^{8}$. Takie przetasowania wzmacniały nieufność ludności do zamieszkiwania w obszarze nadgranicznym.

Po wytyczeniu granicy, całkowitemu oczyszczeniu musiał zostać poddany pas drogi granicznej o szerokości 25 metrów $^{9}$ (zaorany i zabronowany -5 metrów $z$ niego zostawione na droge dla $\mathrm{WOP}^{10}$ ), a na pobyt w strefie granicznej (o szerokości $5 \mathrm{~km}$ - podawano także szerokość $3 \mathrm{~km}^{11}$ ) trzeba było posiadać zezwolenie udzielone ze staro-

5 P. Eberhardt, Zagadnienia ludnościowe obszaru byłych Prus Wschodnich, „Zeszyty Instytutu Geografii i Przestrzennego Zagospodarowania PAN" 1995, nr 29, s. 5-41.

6 A. Wakar, Martwa granica, „Borussia: kultura - historia - literatura” 1992, nr 2, s. 55.

7 R. Traba, Historia pewnej granicy (bez aktualizacji), „Borussia: kultura - historia literatura" 2005, nr 36, s. 66.

M. Płotek, Trudne poczatki. Okręg Mazurski w latach 1945-1946, Dąbrówno 2011, s. 115; E. Romanowska, Skad się wzią obwód kaliningradzki, „Borussia: kultura - historia - literatura" 2005, nr 36, s. 73-82.

9 W Rozporządzeniu Wojewody Olsztyńskiego z dnia 30 listopada 1947 roku wskazuje się, że pas drogi granicznej ustala się na szerokość 15 metrów w głąb kraju. Archiwum Państwowe w Olsztynie (dalej: APO), Urząd Wojewódzki w Olsztynie, Wydział Ogólny, Sprawy różne dotyczące granicy: rok 1947, sygn. 391/73, k. 12.

10 APO, Urząd Wojewódzki w Olsztynie, Wydział Ogólny, Teczka spraw różnych [repatriacja Niemców, drogi graniczne] 1948 rok, sygn. 391/74, k. 53.

11 Ibidem, k. 52. 
stwa $^{12}$. Zaznaczono, że budynki i grunty leżące w strefie granicznej moga ulec wywłaszczeniu na rzecz Państwa, a w odległości $1 \mathrm{~km}$ od linii granicznej może zostać zarządzona wycinka lasów ${ }^{13}$. Ustalono również przebieg strefy nadgranicznej, której zewnętrzną granicę stanowi granica Państwa, a wewnętrzna oddalona jest od 2 do $6 \mathrm{~km}$ od granicy Państwa ${ }^{14}$. Pas graniczny stanowiły natomiast obszary powiatów przyległych do granicy Państwa (oraz gminy innych powiatów, jeśli w całości leżały w zasięgu $30 \mathrm{~km}$ od granicy Państwa) ${ }^{15}$.

Pas i strefa graniczna należały również do tych terenów, które w pierwszej kolejności zostały objęte akcją wysiedlania Niemców, co podano w „Szczegółowym planie repatriacji Niemców” z 3 grudnia 1946 roku, argumentując to następująco:

Odnośnie powiatów Bartoszyce, Braniewo i lławka kładzie się szczególny nacisk, ażeby w pierwszym rzędzie wysiedlono Niemców ze strefy i pasa granicznego W.O.P., gdyż zostało stwierdzone, że w pasie granicznym element niemiecki daje schronienie zbiegłym jeńcom z Z.S.R.R. i zajmuje się przemycaniem Niemców $z$ terenu Z.S.R.R. na teren Polski ${ }^{16}$.

Tak zwane dzikie wypędzenia ludności wschodniopruskiej rozpoczęły się już w 1945 roku. Wspomagane były złym odnoszeniem się do ludności niemieckiej, tak by sama powzięła decyzję o wyjazdach. Organizowano również akcje, podczas których otaczano miejscowości północnych powiatów przez wojsko, rozkazywano szybkie spakowanie rzeczy i konwojowano pieszo w kierunku granicy ${ }^{17}$.

Ostatecznego wytyczenia granicy nie dokonano jeszcze w końcu grudnia 1948 roku. Jej przebieg był wówczas w terenie wyznaczony prowizorycznymi tyczkami. Następnie zaplanowano zmianę oznaczeń na obręcze pomalowane białym wapnem na drzewach od strony polskiej $^{18}$. W 1949 roku do powiatów pogranicznych zaliczano: pow. Goł-

12 APO, Urząd Pełnomocnika Rządu RP na Okręg Mazurski, Sprawy rabunków i bezpieczeństwa, sygn. 390/76, k. 100 (Protokół odprawy starostów powiatów granicznych Województwa Mazurskiego, odbytej dnia 18 lutego 1946 r. w Małej Sali Konferencyjnej Urzędu Wojewódzkiego).

${ }_{13}$ APO, Urząd Wojewódzki w Olsztynie, Wydział Ogólny, Teczka spraw różnych [repatriacja Niemców, drogi graniczne] 1948 rok, sygn. 391/74, k. 52.

14 APO, Urząd Wojewódzki w Olsztynie, Wydział Ogólny, Sprawy różne dotyczące granicy: rok 1947, sygn. 391/73, k. 12 .

15 APO, Urząd Wojewódzki w Olsztynie, Wydział Ogólny, Teczka spraw różnych [repatriacja Niemców, drogi graniczne] 1948 rok, sygn. 391/74, k. 52.

16 APO, Urząd Wojewódzki w Olsztynie, Wydział Inspekcji. Dotyczy napadów, repatriacji, granic: rok 1946, sygn. 391/148, k. 14.

17 Wysiedlenia, wypędzenia i ucieczki 1939-1945. Atlas Ziem Polski, red. W. Sienkiewicz, G. Hryciuk, Warszawa 2008, s. 182; zob. także: G. Białuński, Szymonka (Schimonken). Z dziejów mazurskiej wsi, „Masovia” 1999, t. 2, s. 30.

18 APO, Urząd Wojewódzki w Olsztynie, Wydział Ogólny, Teczka spraw różnych [repatriacja Niemców, drogi graniczne] 1948 rok, sygn. 391/74, k. 53. 
dap w województwie białostockim, w województwie olsztyńskim powiaty: Węgorzewo, Kętrzyn, Bartoszyce, Górowo Iławeckie, Braniewo oraz Elblag w województwie gdańskim ${ }^{19}$.

Niestabilność nowej granicy i bliskość wojsk radzieckich zniechęcała do osiedlania się na terenie nowego pogranicza. Nikt dobrowolnie nie chciał zamieszkiwać w pobliżu stale korygowanej granicy. Duży ruch ludności na nowym, północnym pograniczu Polski odnotowywany był przez całą druga połowę lat 40. XX wieku (zwłaszcza w miesiacach letnich), o czym raportowano w dokumentach Urzędu Wojewódzkiego w Olsztynie.

Niestabilność polityczna oznaczała również wzmożona przestępczość, która na ziemiach przyłączonych była powszechna i wpływała negatywnie na próby stabilizowania sytuacji osadniczej, i tak bardzo dynamicznej, bo determinowanej przesiedleniami i migracjami. Rozboje i kradzieże dokonywane były na przyłączonych terenach nagminnie i na tak dużą skalę, że w krótkim czasie zdążyły się uformować nawet całe polsko-radzieckie bandy zajmujące się paserstwem ${ }^{20}$. W sierpniu 1945 roku raportowano stan bezpieczeństwa na terenie Okręgu Mazurskiego słowami: „Napłynęło z kraju do Okręgu Mazurskiego dużo elementu przestępczego, który unikając pracy zajmuje się włóczęgostwem i tzw. szabrowaniem ${ }^{21}$.

Względne poczucie bezpieczeństwa zapewnić miał m.in. powołany Korpus Ochrony Pogranicza, który w powiatach północnych patrolował przygraniczny pas terenu o szerokości $30 \mathrm{~km}^{22}$. Bataliony Korpusu działały na terenie powiatów: Braniewo, Iławka (Landsberg), Bartoszyce, Węgobork $-z$ dowództwem w Lidzbarku ${ }^{23}$. Sytuacja była na tyle poważna, głównie $z$ powodu napadów żołnierzy, m.in. sowieckich maruderów i stacjonujących oddziałów, jak również band leśnych, że w celu ochrony splądrowanego już poważnie terenu wnoszono o zamknięcie granic powiatów północnych ${ }^{24}$. Powiaty te (wśród nich:

19 APO, Urząd Wojewódzki w Olsztynie, Wydział Administracyjno-Prawny, Sprawy różne (dotyczace repatriacji, strefy granicznej, tajemnicy państwowej), Rok 1949, sygn. 391/221, k. 40-42.

20 W. Brenda, O Armii Czerwonej na Warmii i Mazurach, „Znad Pisy” 2002, nr 11, s. 140.

${ }^{21}$ APO, UP, sygn. 26, k. 15-21; zawarte w: Okreg Mazurski w raportach Jakuba Prawina. Wybór dokumentów. 1945 r., oprac. T. Baryła, Olsztyn 1996, s. 133.

22 Ibidem, s. 211.

${ }^{23}$ Archiwum Akt Nowych (dalej: AAN), Ministerstwo Ziem Odzyskanych, Departament Ekonomiczno-Socjalny, Wydział Statystyki, Ziemie Odzyskane w cyfrach [opracowanie], sygn. 1500a, k. 52.

${ }^{24}$ O zamknięcie granicy powiatu z siedzibą w Górowie Iławeckim wnioskował jego starosta w listopadzie 1945 roku. APO, Urząd Pełnomocnika Rządu RP na Okręg Mazurski, Sprawy rabunków i doniesienia, 1945, sygn. 390/75, k. 102. 
węgorzewski, braniewski, górowski) były najbardziej wyludnione w 1946 roku, jak podaje Stanisław Żyromski ${ }^{25}$.

Dopiero od roku 1947 rozpoczął się napływ osadników do powiatów północnych (braniewskiego, górowskiego, węgorzewskiego) ${ }^{26}$. Miejscowości wyludnionej północy, szczególnie powiatów bartoszyckiego, braniewskiego, elbląskiego, kętrzyńskiego, węgorzewskiego, były zasiedlane przesiedleńcami z południowego-wschodu kraju - głównie ludnością ukraińską ${ }^{27}$. Te tereny do dzisiaj charakteryzuja się dużym udziałem mniejszości ukraińskiej (nie tylko na terenie woj. warmińsko-mazurskiego, ale również w skali kraju) ${ }^{28}$.

Ludność ukraińska i łemkowska została przesiedlona w wyniku akcji „Wisła”, która oficjalnie trwała w dniach 4 maja - 24 lipca 1947 roku. Wówczas na teren województwa olsztyńskiego wysłano koleja 56625 osób (podaje się także liczbę 55518 osób²9, w tym od 4 maja do 2 lipca - 34870 osób) ${ }^{30}$. Z tego około 90 proc. osób osiedlono na terenach wiejskich, według sprawozdań administracji lokalnej, głównie w gospodarstwach bardzo zniszczonych i rozkradzionych ${ }^{31}$. Przykładowo w powiecie nidzickim Ukraińcy musieli zamieszkiwać budynki bez drzwi, okien, a nawet podłóg ${ }^{32}$.

Jeszcze od sierpnia do grudnia 1947 roku przybywały na teren województwa olsztyńskiego mniejsze transporty (np. we wrześniu 1000 rodzin, w grudniu w jednym transporcie 213 osób) ${ }^{33}$. Ludność ukraińska osiedlano przede wszystkim na gruntach pofolwarcznych (19 490 osób), przede wszystkim w północnej części województwa olsztyńskiego: 60 proc. Ukraińców przesiedlonych na byłe wschodniopruskie tereny zamieszkała w powiatach: bartoszyckim, braniew-

25 Okręg Mazurski $w$ raportach..., s. 211.

26 S. Gwiaździński, Miasta i osiedla, „Rocznik Olsztyński” 1966, t. VI, s. 103-105.

27 R. Traba, Historia pewnej granicy..., s. 67.

28 Zob. ryc. 6, w: M. Barwiński, J.A. Wendt, National minorities in Polish politics and its eastern neighbors, „International Journal of Management Academy” 2018, t. 1, s. 31.

29 W poszczególnych powiatach kolejno osiedlono, w: węgorzewskim - 7427, braniewskim - 6675, pasłęckim - 5893, kętrzyńskim - 5102, iławskim - 3326, bartoszyckim - 2951, reszelskim - 2851, ostródzkim - 1598, nidzickim - 940, szczycieńskim - 797, mragowskim - 650, olsztyńskim - 610, piskim - 566. A. Korzeniewska-Lasota, Ukraińny na Warmii i Mazurach w latach 1947-1970, Olsztyn 2007, s. 53-55.

30 Ibidem, s. 53; R.W. Pawlicki, Proces osiedleńczy ludności ukraińskiej $w$ ramach Akcji „Wisła” w powiatach nidzickim, piskim i szczycieńskim, „Rocznik Mazurski” 2008, t. XII, s. $118-119$.

31 Zob. P. Bojarski, E. Janowska, Słowo wstępne, w: Bagaż doświadczeń i wspomnień. Relacje osadników polskich na Warmii i Mazurach po 1945 roku, red. P. Bojarski, E. Janowska, Olsztyn 2017, s. 7-12; także zob. wspomnienia Zofii i Stefana Czebieniaków, w: Bagaż doświadczeń i wspomnień..., s. 143-144.

32 R.W. Pawlicki, Proces osiedleńczy..., s. 118-119.

33 A. Korzeniewska-Lasota, Ukraińcy na Warmii..., s. 55. 
skim, iławskim, kętrzyńskim, pasłęckim i węgorzewskim (największy odsetek w węgorzewskim) ${ }^{34}$. Były to głównie powiaty północne, gdzie w czasie dokonywania przesiedleń znajdowało się najwięcej wolnych zagród. Osadnictwo nie miało charakteru zwartego, zostało celowo rozproszone - przesiedleńcy nie mogli stanowić więcej niż 10 proc. mieszkańców danej osady ${ }^{35}$.

Osiedlanie w zdewastowanych gospodarstwach podkreślane było w dokumentach administracji lokalnej, rządowej i notatkach partii politycznych w latach 50. XX wieku ${ }^{36}$.

Pilnym ze względu na zbliżające się chłody jest chociaż prowizoryczne zabezpieczenie mieszkań zajmowanych przez przesiedleńców z akcji „specjalnej” w szyby, drzwi, sufity, podłogi piece itp. [...] sa i takie rodziny, które osiadły w domach całkowicie „wyszabrowanych”, gdzie przetrwały lato, lecz zima bez skutecznej pomocy i dokładnego wglądu w istotne potrzeby poszczególnego osadnika, sa narażeni na choroby a nawet zamarznięcie ( $z$ notatki korespondenta terenowego Biura Studiów Osadniczo-Przesiedleńczych z powiatu pasłęckiego z września 1947 roku do Ministerstwa Ziem Odzyskanych) ${ }^{37}$.

Po zakończeniu akcji „Wisła”, nadal następowały tzw. przesunięcia ludności ukraińskiej, przesiedlonej na tereny Warmii i Mazur, argumentowane możliwością lub podejrzeniami tworzenia przez nią ruchu oporu. W sprawozdawczości wojewódzkiej z sierpnia 1947 roku podano, że aż 44250 osób z akcji „Wisła” „umieszczonych zostało w strefie zakazanej i kwalifikowało się do przesiedlenia"38. W listopadzie 1947 roku wydano nowe ograniczenia dotyczące osiedlania ludności ukraińskiej, zakazujące rozmieszczania jej w 30-kilometrowym lądowym pasie nadgraniczym i 10-kilometrowym morskim pasie nadgranicznym oraz w odległości $20 \mathrm{~km}$ od miast wojewódzkich. „Przesuwanie” ludności miało miejsce m.in. w 1948 roku na terenie powiatu braniewskiego, w pobliżu granicy polsko-radzieckiej, gdzie stwierdzono zbyt duże zagęszczenie osadników ukraińskich ${ }^{39}$.

Ludności przesiedlonej w ramach akcji „Wisła” towarzyszyło silne poczucie tymczasowości i miała ona największe problemy $z$ adaptacja

34 Ibidem, s. 56.

35 R.W. Pawlicki, Proces osiedleńczy..., s. 110-112.

36 Zob. źródła w opracowaniu: B. Łukaszewicz Kwestia ukraińska na Warmii i Mazurach w latach 1955-1958, „Komunikaty Mazursko-Warmińskie” 1998, nr 4, np. s. 623, 626.

37 AAN, Ministerstwo Ziem Odzyskanych, Biuro Studiów Osadniczo-Przesiedleńczych [Uwagi i informacje korespondentow terenowych o stosunkach na Ziemiach Odzyskanych. 1947-1948], k. 180.

38 A. Korzeniewska-Lasota, Ukraińcy na Warmii..., s. 58.

39 Ibidem, s. 56, 59. 
do nowych warunków spośród wszystkich grup nowych osadników na Warmii i Mazurach. Stan taki utrzymywał się dość długo - w latach 50. $\mathrm{XX}$ wieku w notatkach sprawozdawczych administracji rzadowej nadal pojawiaja się oceny dotyczące poczucia tymczasowości i w związku $\mathrm{z}$ tym niechęci do gospodarowania - np. w związku $\mathrm{z}$ nieuregulowanym prawnym stanem posiadania gospodarstw ${ }^{40}$. W korespondencji administracyjnej i raportach dotyczacych sytuacji terenowej w pierwszych latach powojennych często pojawiały się adnotacje o braku akceptacji nowego miejsca zamieszkania i chęci powrotu na dawne miejsca:

Ludność z powiatów wysiedlonych, nazywają sami siebie Ukraińcami, zupełnie nie bierze się do pracy - czeka powrotu na swoje pozostawione gospodarstwa (z notatki korespondenta terenowego Biura Studiów Osadniczo-Przesiedleńczych do Ministerstwa Ziem Odzyskanych z powiatu Lidzbark Warmiński z lipca, sierpnia 1947 roku) ${ }^{41}$.

Dokonywano nielegalnej ucieczki w rodzinne strony ${ }^{42}$. Pomimo zatrzymywania uciekinierów $z$ województwa olsztyńskiego, po osiedleniu w ramach akcji „W" wyjechało ok. 4-5 tysięcy osób (zezwolenia otrzymało zaledwie ok. 500 osób) ${ }^{43}$. Relacje samych osadników z akcji „Wisła” spisane zostały m.in. w protokole narady „z ludnościa ukraińska zamieszkała na terenie powiatu braniewskiego" z kwietnia 1956 roku i opublikowane $\mathrm{w}$ opracowaniu źródłowym ${ }^{44}$. Znajduja się tam liczne wypowiedzi osadników, dotyczące trudnych warunków materialnych, skargi na nadmierne obciażenia zwiąane $z$ obowiąkkowym odstawianiem na rzecz państwa płodów rolnych oraz niemożnościa powrotu w rodzinne strony, w czym upatrywali poprawę warunków życia. Podobne relacje powtarzały się i w innych protokołach $z$ narad, np. Sylwester Stecik z Bukowca w dyskusji powiedział, że przywieziono ich na te tereny gdzie były gruzy, ruiny i pola zarośnięte. Tam natomiast każdy $z$ nas pozostawił ziemię obsianą i obsadzoną, i budynki w dobrym stanie ${ }^{45}$.

40 B. Łukaszewicz, Kwestia ukraińska..., s. 625, 627.

41 AAN, Ministerstwo Ziem Odzyskanych, Biuro Studiów Osadniczo-Przesiedleńczych [Uwagi i informacje korespondentow terenowych o stosunkach na Ziemiach Odzyskanych. 1947-1948], k. 272.

42 W notatce do Ministerstwa Ziem Odzyskanych z maja 1947 roku o sytuacji w powiecie Lidzbark Warmiński: „Nowo-przesiedleńczy element o wyglądzie ukraińskim bardzo wrogiego charakteru nie ma zamiaru gospodarować i mówią, że będą wracać z powrotem”. AAN, Ministerstwo Ziem Odzyskanych, Biuro Studiów Osadniczo-Przesiedleńczych [Uwagi i informacje korespondentów terenowych o stosunkach na Ziemiach Odzyskanych. 1947-1948], k. 91, zob. także B. Łukaszewicz, Kwestia ukraińska..., s. 634.

43 A. Korzeniewska-Lasota, Ukraincy na Warmii..., s. 67.

44 B. Łukaszewicz, Kwestia ukraińska..., s. 637-644.

45 Ibidem, s. 646, z: 12 kwietnia 1956, Górowo Iławeckie. Protokół narady ludności ukraińskiej $z$ terenu powiatu iławeckiego. 
Pomimo przymusowego sprowadzenia na tzw. Ziemie Odzyskane wielu tysięcy Ukraińców i Łemków, wiele wsi nadal mogło pozostać niedostatecznie zaludnionych. W szczególności dotyczyło to terenów położonych wzdłuż przedwojennych i powojennych granic, względem których wydano zakaz osadnictwa przesiedleńców ${ }^{46}$.

\section{WYLUDNIONE JEDNOSTKI OSADNICZE JAKO MATERIALNA PAMIĘĆ POGRANICZA}

Ustalenie przebiegu granicy polsko-rosyjskiej spowodowało podzielenie między dwa państwa siedlisk 12 miejscowości, a siedliska kolejnych 3 stały się styczne do linii granicznej (zob. tab. 1).

Tabela 1

Miejscowości, których siedliska zostały podzielone granica polsko-rosyjską

\begin{tabular}{|c|c|c|c|c|}
\hline Lp. & $\begin{array}{c}\text { Dawna i/lub współczesna } \\
\text { nazwa miejscowości }\end{array}$ & $\begin{array}{l}\text { Rodzaj } \\
\text { miejscowości }\end{array}$ & $\begin{array}{c}\text { Część } \\
\text { miejscowości } \\
\text { po stronie polskiej } \\
\text { (wartość przybliżona } \\
\text { w \%) }\end{array}$ & $\begin{array}{c}\text { Część } \\
\text { miejscowości } \\
\text { po stronie rosyjskiej } \\
\text { (wartość przybliżona } \\
\text { w \%) }\end{array}$ \\
\hline \multicolumn{5}{|c|}{ Miejscowości zamieszkane } \\
\hline 1 & $\begin{array}{l}\text { Szczurkowo } \\
\text { (niem. Schönbruch) }\end{array}$ & wieś & 40 & 60 \\
\hline \multicolumn{5}{|c|}{ Miejscowości całkowicie wyludnione } \\
\hline 1 & Wermten & wieś & 40 & 60 \\
\hline 2 & Bilshöfen & dwór & 20 & 80 \\
\hline 3 & Deutsch Thierau & wieś & 30 & 70 \\
\hline 4 & Maggen & dwór & 10 & 90 \\
\hline 5 & Rothenen & dwór & 90 & 10 \\
\hline 6 & Rambsen & dwór & 50 & 50 \\
\hline 7 & Braktin & folwark & 50 & 50 \\
\hline 8 & Kanoten & dwór & 60 & 40 \\
\hline 9 & $\begin{array}{l}\text { Schiffuß (przygr.) } \\
\text { (Siworzewo) }\end{array}$ & $\begin{array}{c}\text { wieś } \\
\text { z dworem }\end{array}$ & 100 & - \\
\hline 10 & Sechserben & leśniczówka & 90 & 10 \\
\hline 11 & $\begin{array}{l}\text { Langenfeld (przygr.) } \\
\text { (Dlugopole) }\end{array}$ & wieś & 100 & - \\
\hline 12 & Raude & folwark & 60 & 40 \\
\hline 13 & $\begin{array}{l}\text { Waldkerme (przygr.) } \\
\text { (Piatki) }\end{array}$ & dwór & 100 & - \\
\hline 14 & Torfbruch & osada/kolonia & 90 & 10 \\
\hline
\end{tabular}

Źródło: Opracowanie własne (stan na 2019 rok).

46 Por. R.W. Pawlicki, Proces osiedleńczy..., s. 112. 
Niektóre $z$ miejscowości podzielono ostatecznie niezgodnie $z$ umową graniczną. Przesunięcia granicy dokonywano m.in. biorąc pod uwagę obecność i usytuowanie kościołów na terenach przygranicznych miejscowości. Strona radziecka ze względów strategicznych chciała posiadać te obiekty na swoim terytorium, jako że wieże budynków sakralnych stanowiły dobre punkty obserwacyjne ${ }^{47}$ (np. ryc. 1$)^{48}$.
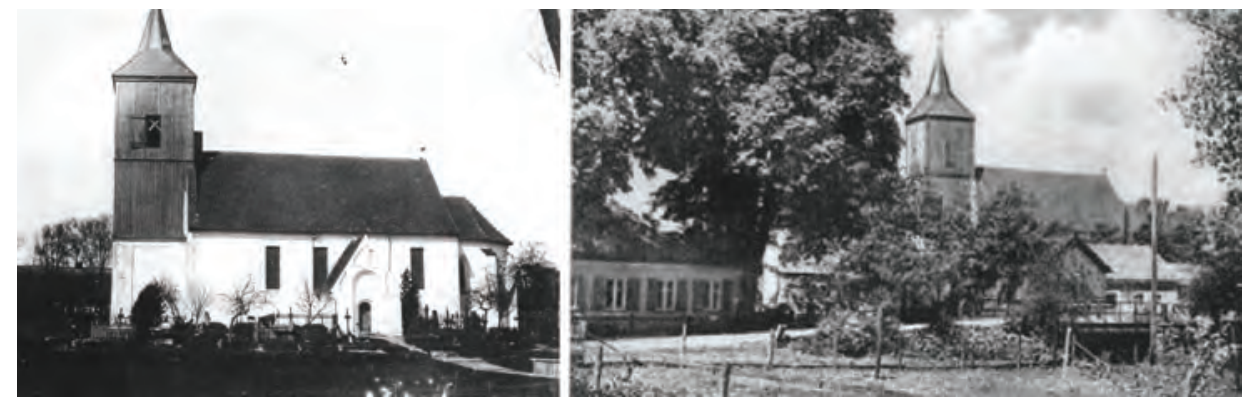

Ryc. 1. Kościół w dawnej miejscowości Deutsch Thierau (fot. ok. 1912 roku)

Źródło:http:/ /wikimapia.org/3852475/pl/Tu-by\%C5\%82a-miejscowo\%C5\%9B\%C4\%87Deutsch-Thierau [dostęp: 23 października 2019].

Sytuacja taka zaistniała np. we wsi Szczurkowo (ryc. 2). Miejscowość przed druga wojna światowa tworzyła zwarta zabudowa gospodarstw skupionych po obu stronach głównej drogi, przylegały do niej założenie dworskie oraz luźno rozrzucone bezimienne przysiółki, składajace się $z$ pojedynczych gospodarstw. Większa część miejscowości - około 60 proc. zabudowy - została włączona do obwodu kaliningradzkiego. Podział został skorygowany przez stronę radziecka na jej korzyść, w ten sposób, aby budynek kościelny znalazł się po tej właśnie stronie granicy. Nowy podział geopolityczny zmienił przestrzenne uwarunkowania dalszego funkcjonowania osad, m.in. na skutek oddzielenia siedlisk wsi od przynależnych do nich pól. Tym samym wiele osiedli, jak podaje Zbigniew Kudrzycki ${ }^{49}$ :

[...] zostało pozbawionych dotychczasowego zaplecza gospodarczego czy oderwanych od możliwości komunikacji $z$ wyższymi jednostkami administracji samorządowej i państwowej.

47 Niezamieszkana pozostaje obecnie dawna wieś Deutsch Thierau, która podzielona została granica i która posiadała budynek kościelny jednowieżowy. Po delimitacji granicy znalazł się on również po stronie rosyjskiej. Kościół podobnie do reszty zabudowy miejscowości został rozebrany, a siedlisko wsi stanowi obecnie teren zalesiony.

48 A. Wakar, Martwa granica..., s. 55.

49 Z. Kudrzycki, Granica polsko-rosyjska przylegajaca do Morza Battyckiego 1945-1958, Toruń 2013, s. 121. 
Tak było również w przypadku Szczurkowa. Dlatego późniejsze korekty przebiegu granicy $z$ końca lat 50 . XX wieku nie dotyczyły terenu samej miejscowości, ale jedynie włączenia do Polski drogi Szczurkowo - Kluczewoje (odcinek o długości 1,85 km - obszar o łącznej powierzchni $18 \mathrm{ha})^{50}$. Po zakończeniu drugiej wojny światowej rosyjska część miejscowości Szczurkowo uległa całkowitemu wyludnieniu. Po stronie polskiej funkcjonuje nieprzerwanie w historycznym układzie zabudowy. Rozbiórce zostały poddane zabudowania należące dawniej do dworu, zajmujace południowo-wschodnią część wsi (ryc. 2).
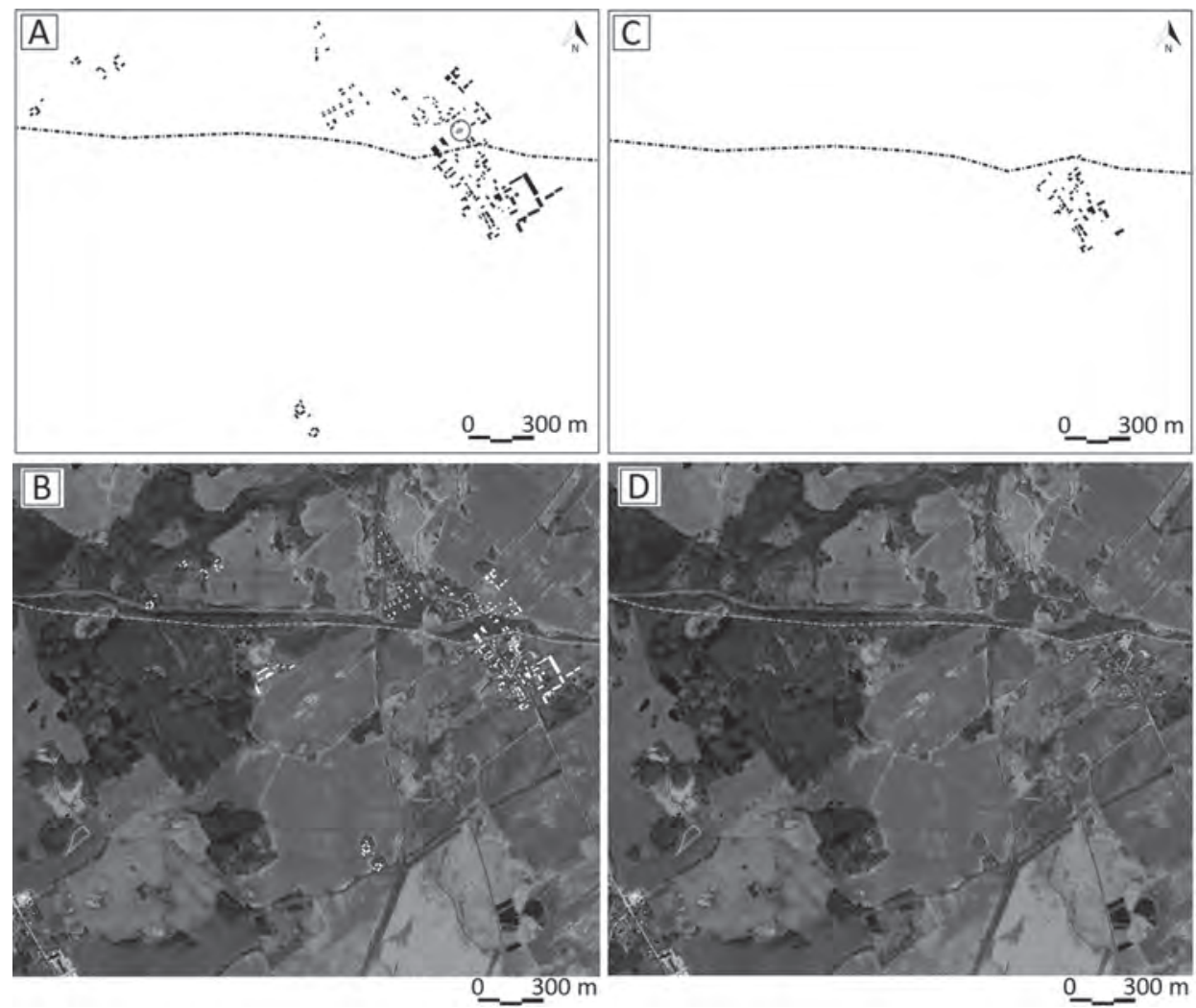

Ryc. 2. Wieś Szczurkowo (powiat bartoszycki): zabudowa miejscowości przed delimitacja granicy (A,B), zabudowa miejscowości współcześnie (C,D) (okręgiem oznaczono lokalizację budynku kościelnego)

Źródło: Wyrys zabudowań z mapy: Topographische Karte Messtischblatt 1:25 000, arkusz 1691, Schoenbruch, 1937; zdjęcie lotnicze: Google Earth - Digital Globe, 2019. Opracowanie własne.

50 Ibidem, s. 194-195. 
We współczesnym krajobrazie pogranicza nadal można zidentyfikować relikty miejscowości, które zostały zlikwidowane na skutek podzielenia granica polsko-radziecka. Najbardziej czytelne sa obszary siedliskowe dawnych osad, wyróżniające się w strukturze krajobrazu jako enklawy płatów gruntu porośnięte zróżnicowaną średnią i wysoka roślinnością (krzewy, drzewa liściaste), która rozwinęła się na terenach dawnych zagród. $\mathrm{W}$ ich obrębie nadal znajduja się liczne pozostałości zabudowy posiadające własne formy terenowe, które sa dobrze identyfikowalne na pochodnych lotniczego skanowania laserowego - cyfrowych modelach ukształtowania powierzchni terenu (NMT) (przykład na ryc. 3A). Interpretacja widocznych obiektów pozwala na wstępne zweryfikowanie i określenie układu zabudowy danej miejscowości, jaki występował w okresie poprzedzającym wyludnienie.

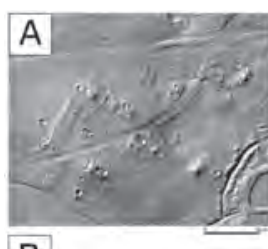

B
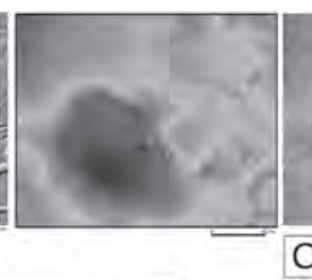

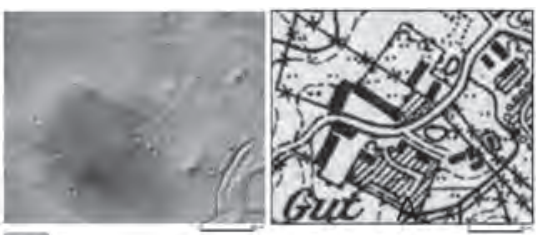

C

GRANICA

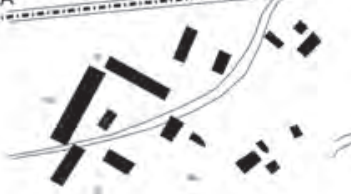

BUDYNKI

INNE OBIEKTY
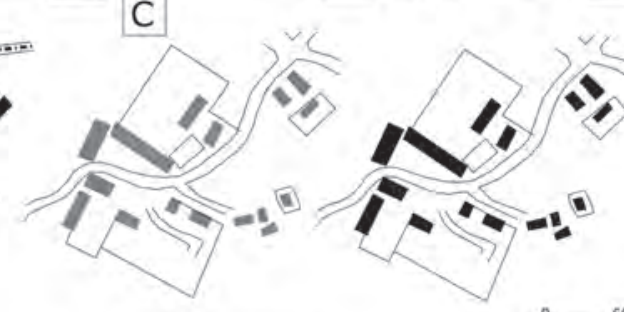

OBIEKTY POSIADAJACE

WEASNA FORME TERENOWA

ZIDENTYFIKOWANA NA NMT

Ryc. 3. Relikty założenia dworskiego Rothenen zidentyfikowane za pośrednictwem pochodnych lotniczego skanowania laserowego (A). Interpretacja zidentyfikowanych obiektów (B) oraz wyrys obiektów $z$ archiwalnej mapy topograficznej (C)

Źródło: Topographische Karte Messtischblatt 1:25 000, arkusz 1689, Pr. Elyau, 1937. Opracowanie własne.

Niestety utrudnione, ze względu na współczesne położenie geopolityczne, jest rozpoznanie reliktów części z miejscowości, które zostały podzielone granica państwowa. Dotyczy to np. majątku dworskiego Bilshöfen, któremu towarzyszyło m.in. historyczne założenie parkowe oraz zespół zabudowy gospodarczej (wycinek mapy - ryc. 4). Pewnych informacji na temat charakteru obiektów tego rodzaju zlikwidowanych miejscowości dostarczają archiwalne materiały fotograficzne. Niektóre 
ze zdjęć wykonanych przed 1945 rokiem na terenie miejscowości Prus Wschodnich zostały zdigitalizowane i zdeponowane w archiwum online, pod adresem: https://www.bildarchiv-ostpreussen.de. Materiały te maja szczególną wartość, zwłaszcza dla tych części miejscowości, które obecnie znajduja się po stronie rosyjskiej i przeprowadzenie tam prospekcji terenowej w celu identyfikacji reliktów nie jest możliwe.

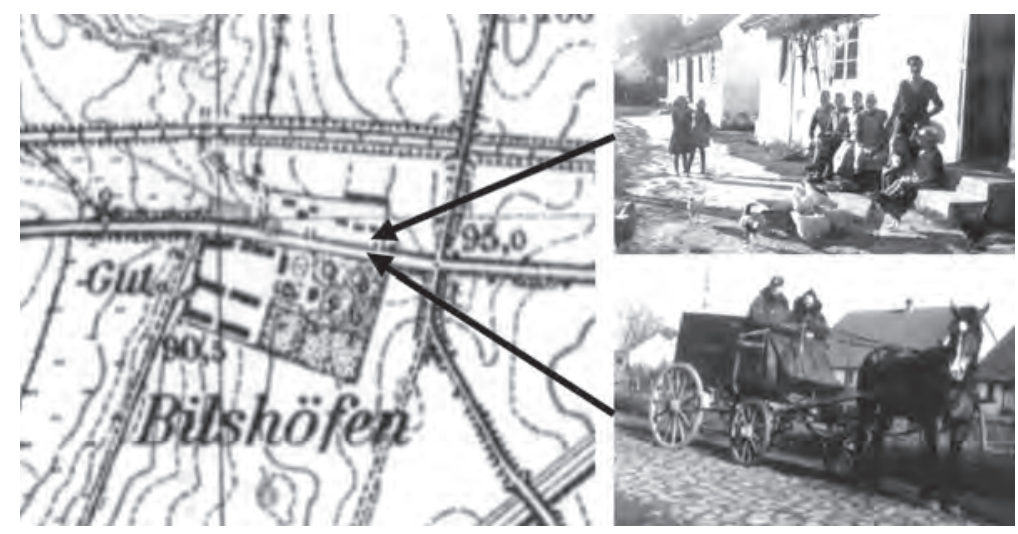

Ryc. 4. Założenie dworskie Bilshöfen - zabudowa zidentyfikowana na fotografiach archiwalnych

Źródło: mapa: Topographische Karte Messtischblatt 1:25 000, arkusz: 1586, 1942; fotografie archiwalne: https:/ /www.bildarchiv-ostpreussen.de [dostęp: 23 października 2019].

Na obszarach i w sąsiedztwie miejscowości, które uległy likwidacji na skutek przecięcia granica państwowa, zaszły istotne zmiany zwiazane $z$ przekształceniami użytkowania gruntów i form pokrycia terenu. Zmiany w użytkowaniu gruntów sa zauważalne zwłaszcza po stronie rosyjskiej, gdzie pola orne zamieniono na nieużytki, a w większości zalesiono. Pogranicze $z$ obwodem kaliningradzkim jest szczególne, jako że północna część Prus Wschodnich po zakończeniu drugiej wojny światowej stała się obszarem zmilitaryzowanym, terenem właściwie eksperymentalnego osadnictwa - społeczności w jednej trzeciej złożonej z żołnierzy $^{51}$. Na terenie obwodu kaliningradzkiego, jak podaje Jan Salm:

Współczesny krajobraz obłasti zawiera wiele luk, dziur i pustek po zniszczonych budowlach, wsiach, dworach i czasem całych miastach. W wielu miejscach destrukcja historycznego krajobrazu jest przytłaczająca ${ }^{52}$.

51 M. Dębicki, Obwód kalinigradzki i polsko-kalinigradzkie sasiedztwo w perspektywie społeczno-historycznej, „Borussia: kultura-historia - literatura” 2009, nr 43, s. 138; E. Romanowska, Skad sie wział obwód kaliningradzki, „Borussia: kultura - historia - literatura” 2005, nr 36, s. 76.

52 J. Salm, Po obwodzie, czyli krótka wyprawa do Darkiejm, Gąbina i Wystruci, „Borussia: kultura - historia - literatura" 2009, nr 40, s. 106. 
Po stronie polskiej przekształceniu w nieużytki podlegaja niemal wyłącznie jedynie same dawne siedliska miejscowości, podczas gdy ich rozłogi sa nadal eksploatowane rolniczo. Procesy zmian bądź kontynuacji użytkowania gruntów prześledzić można na przykładach m.in. osad Wermten oraz majątku dworskiego Bilshöfen (ryc. 5 i ryc. 6). Zmiany rodzajów pokrycia terenu w obrębie współcześnie niezamieszkanych miejscowości, których siedliska zostały rozdzielone granica polsko-rosyjska, obejmuja przede wszystkim intensywną sukcesję
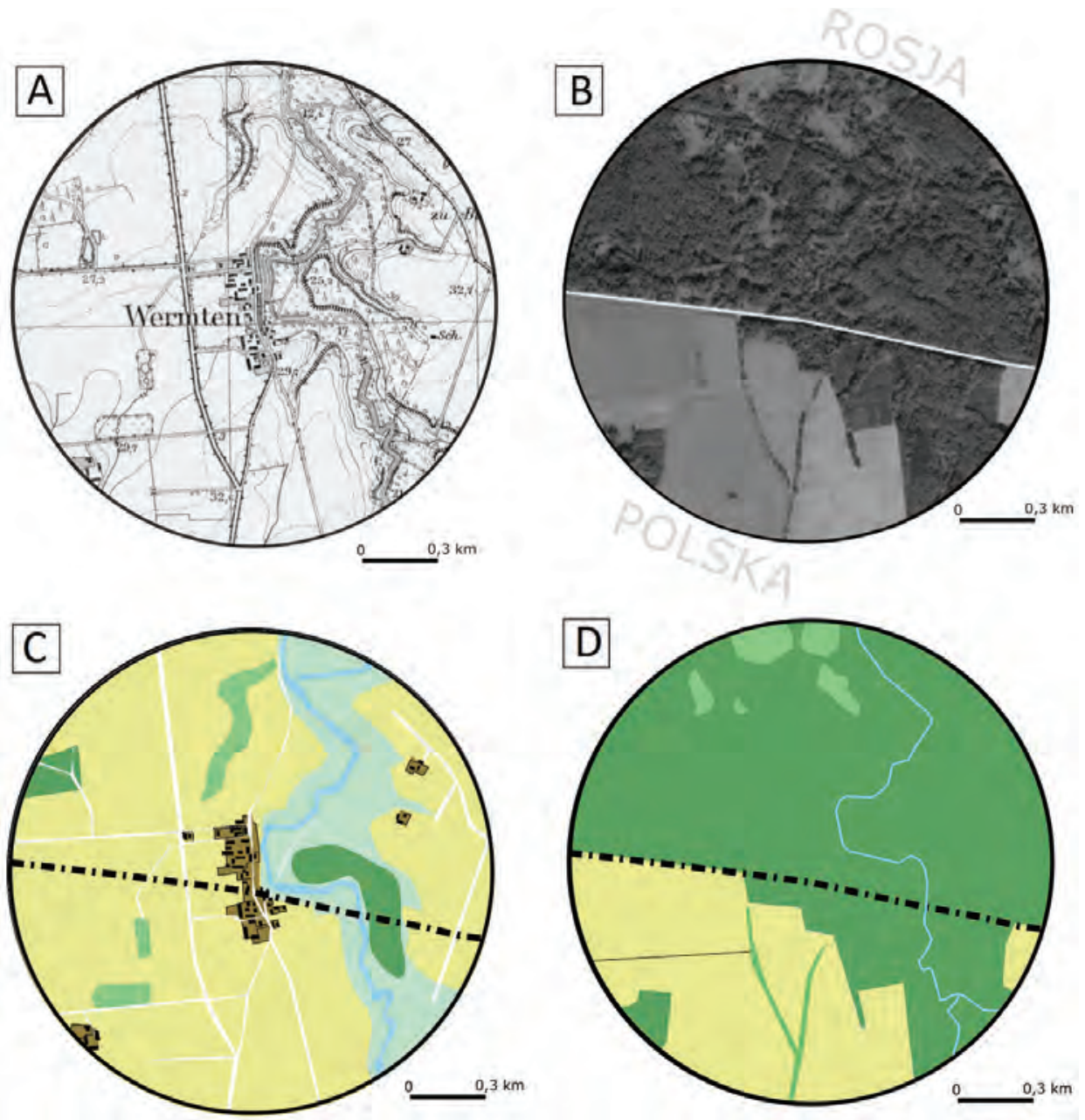

Ryc. 5. Podzielona granica polsko-rosyjska całkowicie wyludniona miejscowość Wermten, pow. braniewski: A - na mapie Topographische Karte Messtischblatt 1:25 000, arkusz 1585, Heiligenbeil, 1940;

B - na obrazie satelitarnym Google Earth, 2018; C - formy pokrycia terenu w roku 1940; D - formy pokrycia terenu w 2018 roku. Opracowanie własne. 

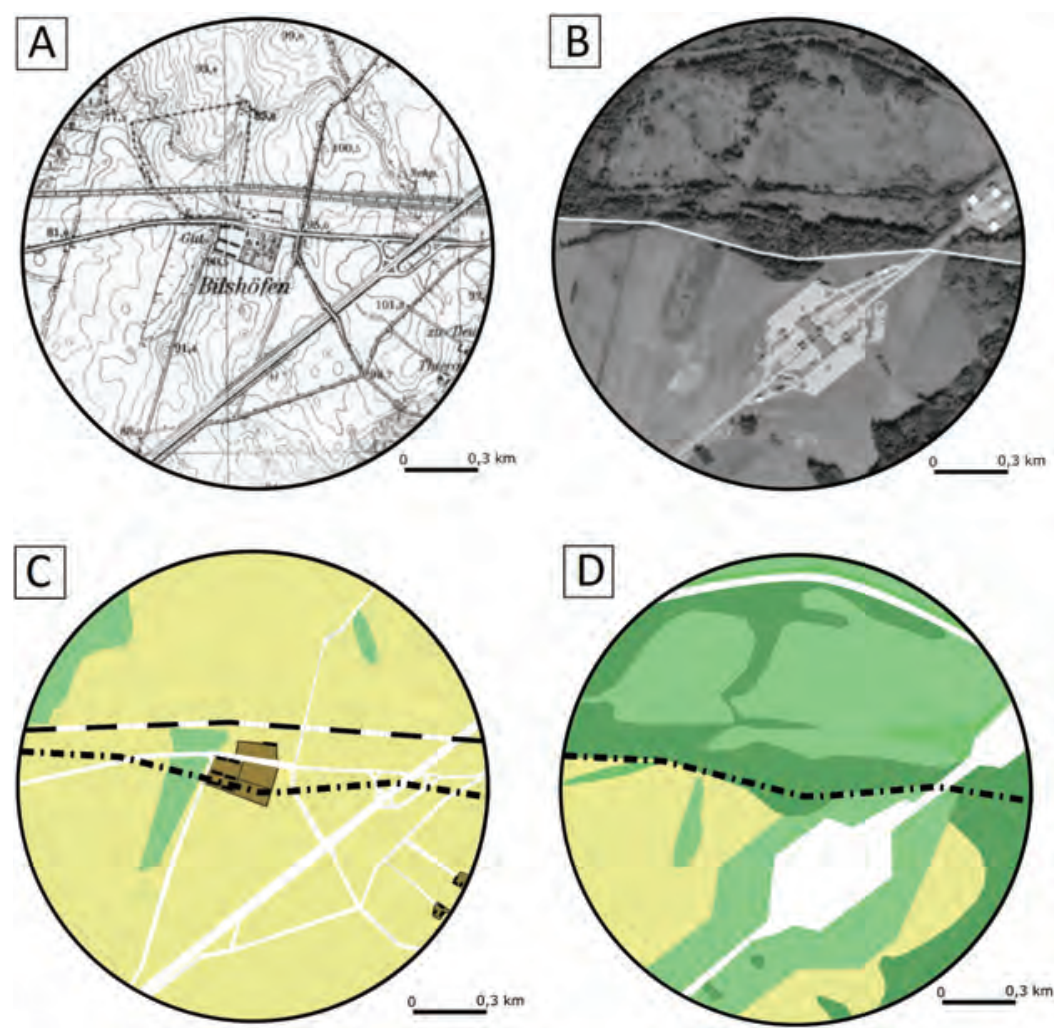

Ryc. 6. Podzielony granica polsko-rosyjska całkowicie wyludniony dawny majatek dworski Bilshöfen, pow. braniewski:

A - na mapie Topographische Karte Messtischblatt 1:25 000, arkusz 1586, Deutsch Thierau, 1942; B - na obrazie satelitarnym - Google Earth, 2018;

C - formy pokrycia terenu w roku 1942; D - formy pokrycia terenu w 2018 roku. Opracowanie własne.

roślinności (zob. ryc. 7). Tylko w pojedynczych przypadkach zmiany powiazane były np. $z$ powstaniem nowej infrastruktury koniecznej ze względu na obsługę ruchu granicznego (ryc. 6 - Bilshöfen, także miejscowość Rothenen). Na obszarach wcześniej intensywnie użytkowanych gospodarczo, w tym dawnych zagród, na skutek przerwania ciągłości osadnictwa, po poczatkowych procesach destrukcyjnych (np. grabież i rozbiórka zabudowań), zaczęły stopniowo zwiększać swój udział procesy przyrodnicze. Miejscowości zmieniały się w nieużytki zarastające roślinnością ruderalną i samosiewami, tworząc $z$ biegiem lat nieregularne drzewostany porastajace swego rodzaju naturo-kulturowe przestrzenie zanikających pod względem materialnym jednostek osadniczych. 


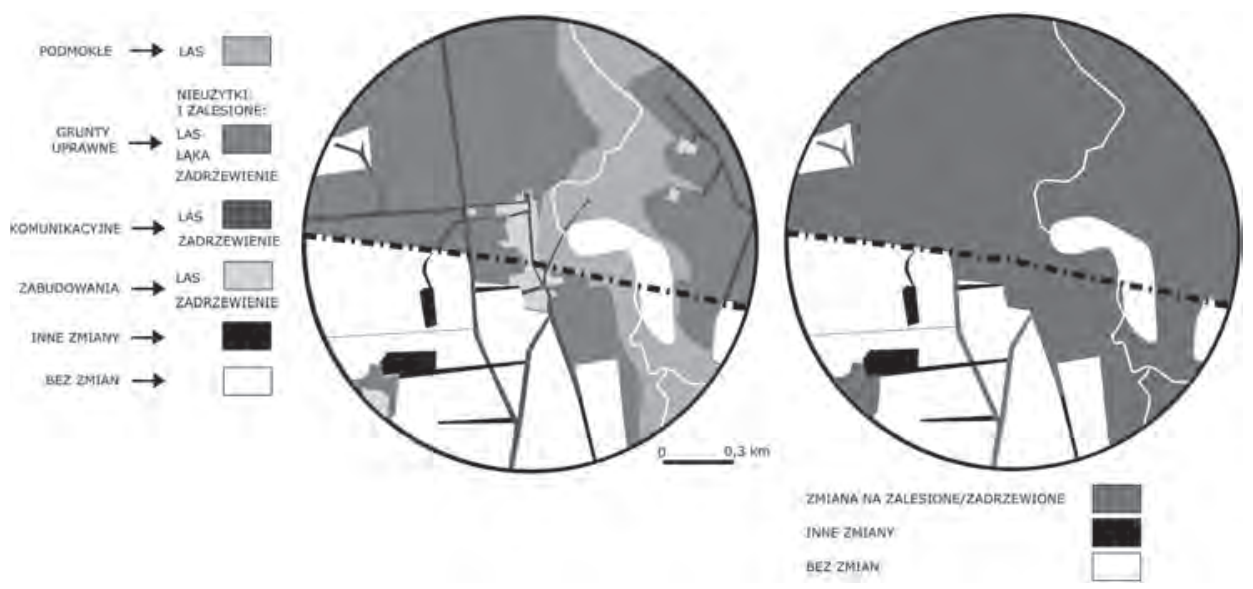

Ryc. 7. Zmiany form pokrycia terenu w przykładowych miejscowościach w przedziale 1940/1942 - 2018. Opracowanie własne.

Udział jednostek podzielonych granicą wśród niezamieszkanych miejscowości znajdujących się we włączonej do Polski części Prus Wschodnich jest w zasadzie minimalny, bo stanowi zaledwie niewiele ponad 1 proc. Wpływ wytyczenia granicy na krajobraz kulturowy i zanik osadnictwa można zaobserwować, włączając do analizy również tereny $z$ nia sasiadujace. W obszarze pogranicza polsko-rosyjskiego, w pasie o szerokości $5 \mathrm{~km}$ wytyczonym od linii granicznej, poza wymienionymi znajdują się 73 (razem 85) całkowicie wyludnione miejscowości. W kolejnym 5-kilometrowym pasie zidentyfikowano jeszcze 52 niezamieszkane miejscowości ${ }^{53}$. Łacznie w 10-kilometrowym pasie pogranicza wzdłuż całego 210-kilometrowego odcinka granicy polsko-rosyjskiej zlokalizowanych jest zatem 137 całkowicie wyludnionych miejscowości (stan na 2019 rok), a w odległości $20 \mathrm{~km}$ od granicy znajduje się łącznie 248 takich miejscowości (ryc. 8).

Rozmieszczenie wyludnionych miejscowości w ramach sieci osadniczej jest nierównomierne i nie przedstawia większego związku $z$ układem szlaków komunikacyjnych (sieci drogowej) oraz z rozmieszczeniem średnich i dużych miast (zob. np. położenie miejscowości niezamieszkanych w sasiedztwie miasta Bartoszyce - ryc. 9) ${ }^{54}$.

${ }^{53} \mathrm{~W}$ kolejnych 5-kilometrowych pasach terenu wyznaczonych od granicy polsko-rosyjskiej zidentyfikowano kolejno 61 i 50 całkowicie wyludnionych miejscowości (zob. ryc. 8).

${ }^{54}$ Wyjątek na obszarze włączonej do polski części Prus Wschodnich stanowi położony na Warmii Olsztyn, gdzie obecność wyludnionych miejscowości w promieniu $30 \mathrm{~km}$ od centrum miasta jest najmniej liczna. 


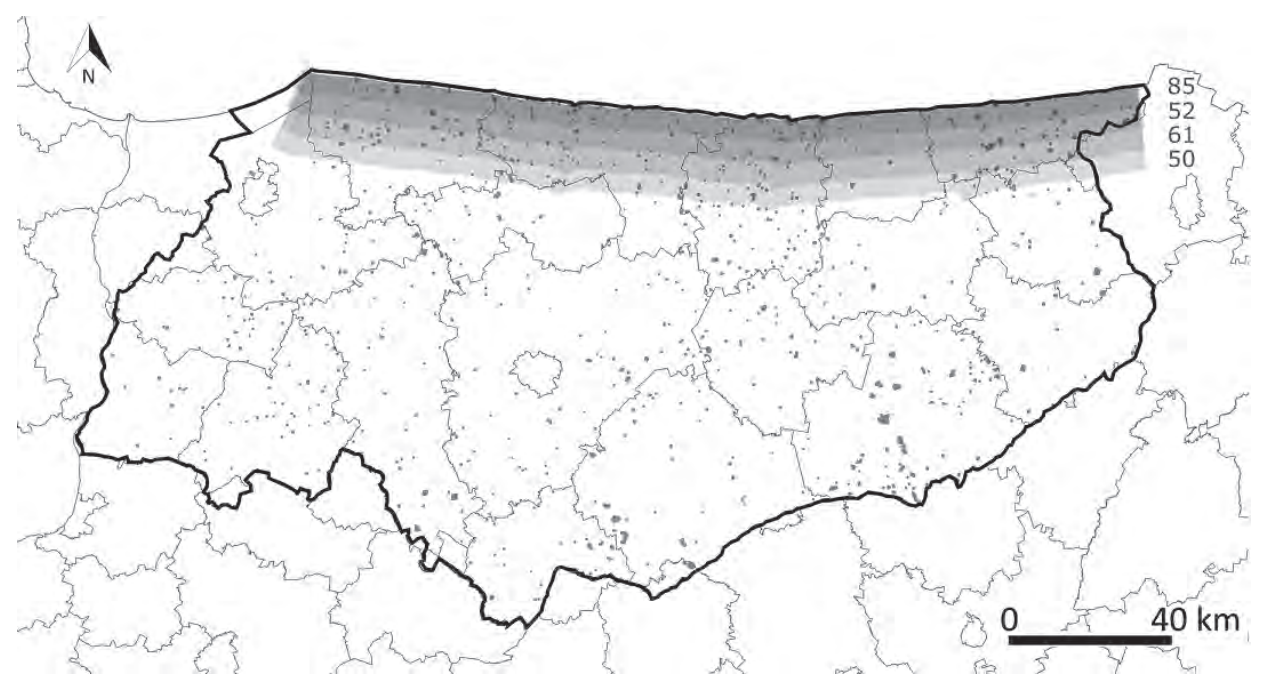

Ryc. 8. Całkowicie wyludnione miejscowości w polskiej części dawnych Prus Wschodnich. Pogranicze polsko-rosyjskie $z$ oznaczonymi pasami o 5-kilometrowej szerokości. Opracowanie własne.

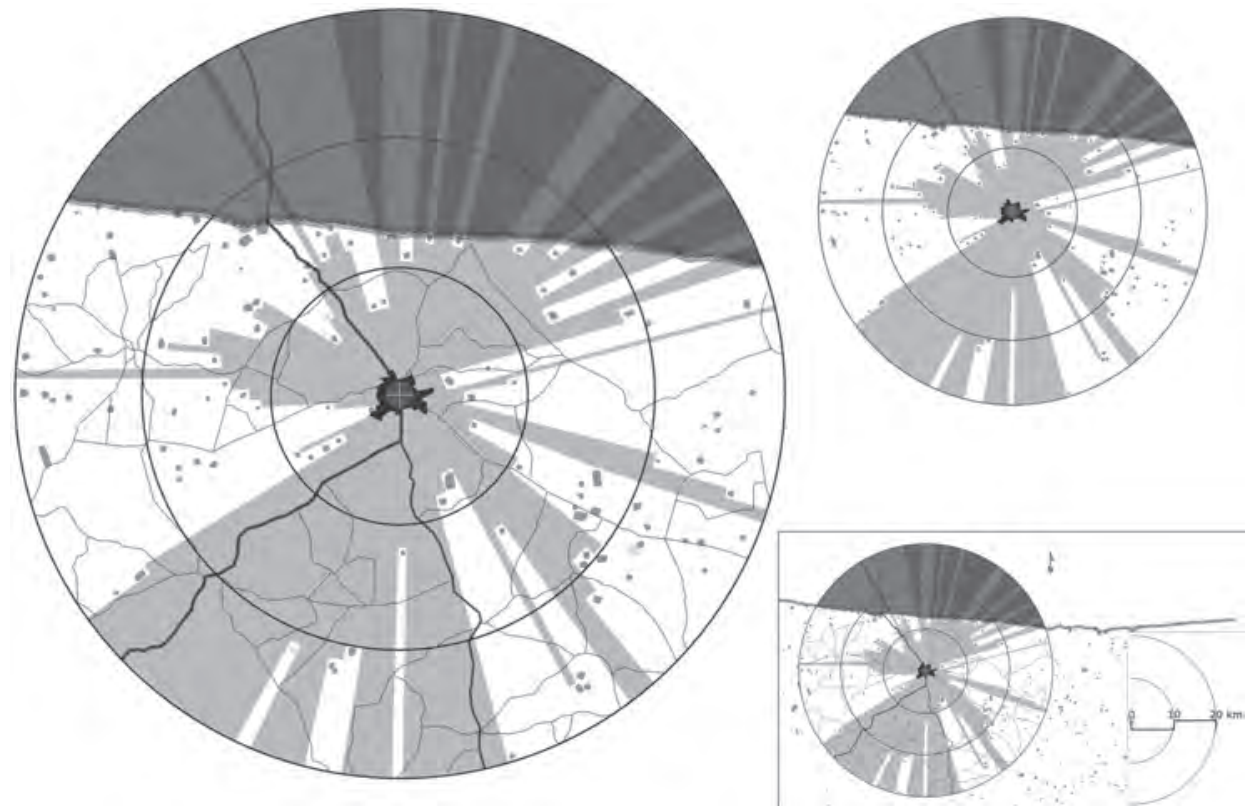

Ryc. 9. Fragment pogranicza polsko-rosyjskiego.

Odległości od centroidu miasta Bartoszyce do całkowicie wyludnionych miejscowości (przedstawione na tle sieci drogowej). Opracowanie własne. 
Na podstawie dotychczasowych analiz można wysunąc tezę, że stan obecny stanowi konsekwencje gwałtownych przemian społeczno-politycznych końca drugiej wojny światowej i okresu tużpowojennego, kiedy następowały masowe migracje ludności powodujące niemal całkowita jej wymianę i przerwanie ciagłości kulturowej obszaru (w tym kultury gospodarczej i rolnej). Zerwanie ciagłości dotychczasowego modelu osadniczego, w którym ważne miejsce zajmowały osady o charakterze jednodworczym (głównie samodzielne założenia dworskie i folwarczne), doprowadziło do upadku wielu małych miejscowości.

\section{WNIOSKI I PODSUMOWANIE}

Miejscowości, które zostały podzielone granica polsko-rosyjska mają niewielki udział wśród całkowicie wyludnionych jednostek osadniczych w polskiej części dawnych Prus Wschodnich, stanowia jednak istotne elementy współczesnego pogranicza i jego burzliwej historii. Ich przestrzenie nadal wyróżniają się w krajobrazie, tworząc odrębne płaty w strukturze terenu, na które składaja się przede wszystkim relikty posiadające własne formy wraz $z$ rozwijającymi się przez dziesięciolecia zbiorowiskami roślinnymi.

$\mathrm{Na}$ występowanie dużej liczby całkowicie wyludnionych miejscowości na pograniczu polsko-rosyjskim wpływ miało wiele czynników. Część $z$ nich związana jest $z$ samym charakterem sieci osadniczej tych terenów sprzed rozpoczęcia drugiej wojny światowej. W powiatach, które zostały podzielone granicą w 1945 roku, był duży udział niewielkich jednostek osadniczych, w tym zwłaszcza założeń dworskich i folwarcznych, które podczas i po zakończeniu działań wojennych zostały opuszczone przez dotychczasowych mieszkańców. Na skutek powojennych wysiedleń ludności miejscowej gospodarstwa te narażane były kolejno na grabież i dewastację. Te, które nie uległy całkowitemu zniszczeniu, zostały ponownie zasiedlone ludnością napływowa, która niechętnie podejmowała trud organizacji życia w zagrodach o często długo nieustalonym statusie własności. Permanentne poczucie tymczasowości sprawiało, że ludność dokonywała nielegalnych ucieczek $z$ terenów przygranicznych, niepewna bieżącej sytuacji politycznej. Kresu wielu majątków dopełnił również okres transformacji ustrojowej lat 90. XX wieku, kiedy prywatyzacja, a więc i upadek Państwowych Gospodarstw Rolnych powodował opuszczenie wielu dotychczas 
eksploatowanych majątków. To po tym ostatnim etapie „wyludniania” pozostały jeszcze w dawnych założeniach dworskich i folwarkach budynki, które stanowia materialne świadectwa dokonujących się procesów. To one obok trudno dostępnych - bo poddanych już pewnej krajobrazowej transformacji - reliktów, opuszczonych w latach 40. do 70. XX wieku miejscowości, stanowią elementy pamięci krajobrazu kilkudziesięcioletniego pogranicza. 